\title{
THE IMPACT OF INCREASING EGYPTIAN EXTERNAL DEBT ON THE SUSTAINABLE DEVELOPMENT GOALS "EGYPT 2030"
}

\author{
Mosaad M. Elgayish \\ Assistant Professor of Economics at Economics Department, \\ Faculty of Politics \&Economics, Beni-Suef University, Egypt. \\ DOI: 10.46609/IJSSER.2020.v05i01.001 URL: https://doi.org/10.46609/IJSSER.2020.v05i01.001
}

\begin{abstract}
The period from 2016 to 2019 witnessed a noticeable increase in the Egyptian external debt. Egypt has adopted the sustainable development plan "Egypt 2030". The research problem was to what extent does the increasing Egyptian external debt affect the goals of the sustainable development plan "Egypt 2030"?The simple regression model was used to show the relationship between the Egyptian external debt as an independent variable and each of the goals of the sustainable development plan as dependent variables, relying on World Bank data, the inverse model was used to indicate the relationship between external debt and per capita GDP, and the Quadratic model was used to clarify the relationship between external debt and the unemployment rate. The research concluded that, there is a varied effect of increasing external debt on the goals of the sustainable development plan, "Egypt 2030". All results are conditional on the condition that the public debt be sustainable and the ability to pay the premiums and interest at the time they are due, and therefore the study recommended the need to review the policy of managing external debt in particular and the public debt in general with regard to its negative impact on price increases only, and that it is directed to investment areas. On the whole, there is no need to be disturbed by the increase in external debt, provided the public debt is sustainable and the ability to pay installments and interest on time and provided that it is directed to investment.
\end{abstract}

Keywords: External debt, Egypt 2030, Goals, Sustainable development

\section{INTRODUCTION}

Egypt passed a set of development plans, especially in the period between the fifties and seventies, where economic development programs in Egypt during that period focused on protecting the emerging industry, and in 1973 Egypt adopted a policy of economic openness and 


\section{International Journal of Social Science and Economic Research}

increased dependence on foreign financial resources to finance the economic development process. In 1978, Egypt signed an agreement with the International Monetary Fund (IMF) that included Egypt adopting an economic adjustment program based on credit facilities and financial support provided by IMF for a period of 3 years amounting to $\$ 720$ million. Then Egypt adopted a strategy to encourage exports during the eighties and nineties. (Youssef, Mohamed Hassan, 2008) Then Egypt implemented a set of economic reform programs recommended by the IMF in 1990, but a gap remained in the financial resources that required its coverage to rely on external financing (Moussa Ibrahim, 2009). The talk about sustainable development in Egypt has become uninterrupted, especially after the state embarked on a comprehensive reform process since 2014 and after the announcement by the Egyptian Ministry of Planning of the sustainable development plan - Egypt 2030. However, the problem of public debt, which has become a problem for many countries in the world, especially developing countries, stands in the way of achieving the desired goal, including the risks of accumulating interest and payment in time, especially if it exceeds the safety limit as a result of the rapid increase in public spending. The total Egyptian external debt in 1993 amounted to about 30.9 billion dollars, then in 1997 it decreased to 28.8 billion dollars, then to 28.7 billion in 2002, and the size of the Egyptian public debt has increased significantly recently, as the proportion of public debt in Egypt reached about $90.3 \%$ of the total The domestic product in 2009, the Egyptian public debt increased in the years 2013-2014 to a noticeable degree, as the external debt exceeded 45 billion dollars, and the domestic debt reached more than one billion and 400 million pounds. (Egyptian Ministry of Finance, 2013). Then the external debt continued to increase, reaching 48 and 60 billion dollars in 2015 and 2016 respectively, then it jumped to 79 billion dollars in 2017 and then 92 billion dollars in 2018 before it exceeded 100 billion dollars before the end of fiscal year 2019 (World Bank 2019). This is what stopped the researcher, as the leaps of increasing the Egyptian external debt became accelerating and could affect the sustainable development plan adopted by Egypt.

\section{THE RESEARCH PROBLEM AND PURPOSE}

The researcher has noticed an increase in the Egyptian external debt significantly during the years 2017, 2018 and 2019 respectively, with more than 50 billion dollars. Therefore, the research problem can be crystallized in how does the increase of the Egyptian external debt affect the goals of the sustainable development plan "Egypt 2030"? Therefore, the research aims to determine the extent of the impact of the increasing Egyptian external debt on the goals of the sustainable development plan - Egypt 2030, which the Arab Republic of Egypt adopted in February 2016 and is working hard to achieve. The importance of the research comes from its research on a topic that has become the starting point of modern Egypt towards an economically advanced society at all levels. The research also studies the Egyptian external debt and its impact on the development process from 1990 to 2019. 


\section{International Journal of Social Science and Economic Research}

ISSN: $2455-8834$

Volume: 05, Issue: 01 "January 2020"

\section{LITERATURE REVIEW}

Diamond indicated that the economic effects of public debt on neoclassical analysis on savings are significant if they are intended to cover a permanent budget deficit. However, the short-term economic impact of these loans on savings may be very small if the debt is to cover short-term temporary deficits (Diamond, Peter 1965). Also Benjamin pointed out that the large public debts of the United States of America showed its impact on the low standard of living of individuals and on the low role of America in international affairs (Benjamin Friedman, 1988). While the study (Jayaraman T.K, 2008) concluded that the increase in the flow of external debt and also foreign aid has contributed significantly and clearly to increasing the rate of economic growth in six countries of the Pacific during the period from 1988-2004. In another study (Ejigayehu, Dereje Abere, 2013) examined the impact of external debt on the economic growth of eight heavily indebted African countries between 1991 and 2010, the study concluded that external debt affects economic growth by accumulating debts. The countries selected for the study also found that they do not pay debt service for more than $95 \%$ of their accumulated debt. While the study (Yalgin Suleiman 2013) concluded that the results related to the impact of external debt on economic growth were varied after studying the impact of debt on growth in a group of Southeast Asian countries for the period from 1990 to 2008, where positive effects of external debt appeared on the output in Malaysia and the Philippines where The external debt reaches the excessive level, after which the external debt adversely affects. And others are negative, such as Indonesia and Thailand. The study (Al-Basha \& others, 2014) examined the impact of external financing on economic growth in Jordan and concluded that the increase in external debt negatively affects economic growth in Jordan and attributed the reason for this to the fact that the external debt is directed to consumption and not to investment.

While another study about, the impact of external debt on the economic growth of some Arab borrowing countries for the period 2000-2013, (Mustafa. Samir 2015) concluded that there is an inverse relationship between the external debt and the local product. In a study (Pentor AlMustafa, 2018) on the limits of sustainable public debt and economic growth between theory and reality for some Arab countries, the study reached several conclusions, including that there is no common ceiling for public debt that applies to all Arab countries similar to the ceiling of the estimated Maastricht criterion At $60 \%$ of the output and it was justified due to the different economic and structural characteristics that differ from one country to another. The study also showed that in some Arab countries after exceeding public debt certain limits, the relationship between debt and economic growth turns into an inverse relationship after it was positive. While the researcher tries to measure the impact of the increase of the Egyptian external debt on the goals of the sustainable development plan - Egypt 2030, Which Egypt adopted in February 2016. 
International Journal of Social Science and Economic Research

ISSN: $2455-8834$

Volume: 05, Issue: 01 "January 2020"

\section{RESEARCH HYPOTHESIS \& METHODOLOGY}

The research assumes that the increase in the Egyptian external debt has a different effect on the sustainable development goals "Egypt 2030", as it may negatively affect some development variables and positively on others. The simple regression model was used to show the relationship between the Egyptian external debt as an independent variable and each of the Egyptian trade balance deficit as a percentage of gross domestic product, per capita gross domestic product, unemployment rate, inflation rate, and the state's public budget deficit as dependent variables, relying on World Bank data and these dependent variables that were studied on were targeted by the Egyptian Ministry of Planning and reached the limits set within the sustainable development plan Egypt 2030, and the inverse model was used to indicate the relationship between external debt and per capita GDP, and the Quadratic model was used to clarify the relationship between external debt and the unemployment rate, and a Quadratic model was used to show the degree of the impact of external debt on the Egyptian public budget deficit. All the previous variables are stable. As for the variables of the inflation rate and the deficit of the trade balance and the extent of the impact of the external debt on them, a linear model was used $^{1}$. Also, the model does not suffer from self-correlation using the serial correlation LM test. The model does not suffer from instability of variance using the Heteroskedasticity Test. The rest also follow the normal distribution using the Histogram-Normality Test. It is also noted that all models Linear, Logarithmic, Inverse, Quadratic, Cubic, Compound Power, Growth, Exponential Logistic $\mathrm{S}$, which clarify the relationship between GR, EXD is not significant, which means that EXD does not affect GR.

\section{EGYPTIAN EXTERNAL DEBT}

Egyptian public debt consists of all the loans obtained by the state from internal and external loans and their interest until a certain date (Omar Mohammad Abdel Halim, 2003). The internal debt is broadly understood in the loans obtained by the government, economic public bodies, and the National Investment Bank, and by excluding the indebtedness of the National Investment Bank it could get the internal debt in its narrow sense. As for external debt, it is a reflection of the loans obtained by the state from countries and international institutions. ${ }^{2}$ It includes loans from international and regional institutions, and net deposits of non-residents in the banking system. ${ }^{3}$ The total Egyptian external debt in 1993 amounted to about 30.9 billion dollars, then it

With a significant level of $1 \%{ }^{1}$ It is the existing obligations (debt stock) in foreign currency against residents against non-residents and it is settled ${ }^{2}$ or settled in foreign currency. For residents: individuals or entities residing in Egypt, and non-residents: foreigners .are institutions, governments, or individuals In terms of the debtor sector, it consists of government debt, debts on the monetary authority (the central bank), ${ }^{3}$ debts on banks, and private sector debt 
International Journal of Social Science and Economic Research

ISSN: $2455-8834$

Volume: 05, Issue: 01 "January 2020"

decreased in 1997 to 28.8 billion dollars and then to 28.7 billion in 2002, although at the time when the total external debt decreased from 31.1 billion in 1994 to 29 billion dollars in 2006, for example it found that the total external debt burdens increased from \$1.9 million in 1994 to $\$$ 3.5 million in 2006, due to the fact that the debt burdens that were canceled under the Paris Club remained outstanding and payable, but rose to 33.89 billion dollars in 2008 and in 2013 it rose to reach 45 billion dollars. Then it jumped to $\$ 60$ billion in 2016 and then 79 billion in 2017, in 2018 it continued to rise to $\$ 92$ billion before it exceeded $\$ 100$ billion before the end of fiscal year 2019 (The World Bank, 2019).

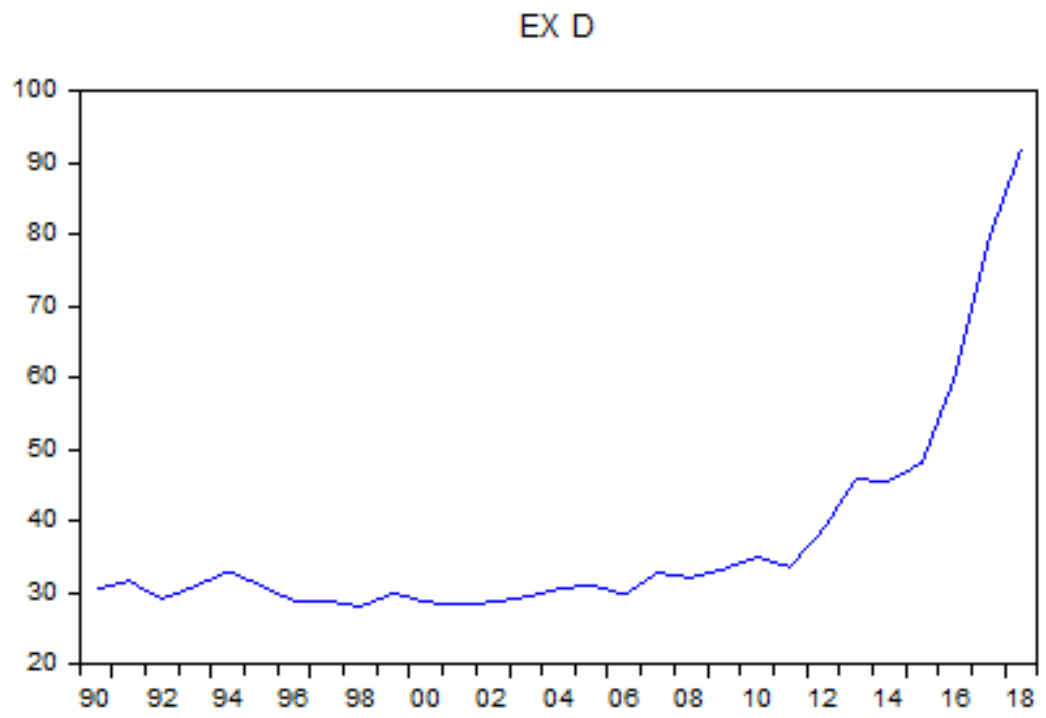

\subsection{IMF loan 2016}

During the era of President Sadat, Egypt requested a loan from the IMF in 1987 worth \$ 185.7 million to solve the problem of late external payments, in addition to increasing the rate of inflation at that time. The attempt to obtain the loan failed as a result of the difficulty in implementing the fund's requests, which was to reduce the value of the Egyptian pound to treat the budget deficit, and the high inflation rate. Then other negotiations followed in 1991 to obtain a loan to implement some economic reforms, and Egypt had already obtained a loan of \$ 375.2 million to cover the trade deficit (Shalaby Nadia, 2014). Then, in 1996, Egypt requested another loan from the IMF, worth $\$ 434.4$ million, and IMF did not agree to it. However, at that time, IMF agreed to cancel $50 \%$ of his debts owed by member states of the Paris Economic Club and in 2011 Egypt requested another loan of 3.2 billion dollars, whose value increased to 4.7 billion dollars in 2014 and Egypt did not obtain it. Finally, in 2016, a 12 billion dollar loan was already approved, and Egypt has already obtained the loan for extensive economic reforms and sustainable development goals. The loan was represented in 6 tranches, which includes a grace 
period of about four and a half years for each tier of the loan. Each tranche of the loan must be repaid within a period of five and a half years. ${ }^{4}$ Egypt will start repaying the first tranche of the loan starting from 2021, and the last tranche will be repaid in 2029 (Egyptian Ministry of Finance 2019 (Egyptian Ministry of Finance 2019).

\subsection{Russia's Loan (Dabaa Nuclear Energy Project)}

By signing the agreement with Russia to advance the renewable energy project, which is the construction of a nuclear power plant in Dabaa, in the Egyptian Western Desert, Russia has provided a loan that is the largest in the history of the Egyptian external debt, worth $\$ 25$ billion, and the agreement stipulated that the loan be used by the Egyptian party to finance $85 \%$ of the project's cost, The Egyptian party pays the remaining $15 \%$. The agreement also stipulated that the loan be used over a period of 13 years from 2016 to 2028 and it will be received in installments that end in 2028. Interest on the loan begins immediately with the receipt of the first payment of the loan at an annual interest rate of 3\%..$^{5}$ Total foreign debt interest in 2015-2016 amounted to about 6.9 billion pounds, and the external public debt installments reached 39.6 billion pounds, and after obtaining payments from the Russian loan and at peak times to pay the Russian loan service to $\$ 1.9$ billion (EIPR Personality, 2017) which is what he must prepare for now.

\section{THE DEGREE OF INFLUENCE OF EXTERNAL DEBT ON THE SUSTAINABLE DEVELOPMENT GOALS 2030}

The classic cared about explaining the obstacles to economic development, in which they pointed to population pressures coupled with the scarcity of natural resources, especially capital, as the neoclassic pointed to an analysis of the savings and investment process and the implications of increasing any of them on the other, as Karl Marx wrote a complete book on capital and its importance in the production process, Schumpeter's theory also focused on highlighting the role of the regulator in the process of capital accumulation necessary to finance the development process. Keynes's theory was demonstrated the motivations for money demand, including speculative motivation after transactions and emergency, and highlight the importance of the interest rate in encouraging investment (Ajamiyeh Mohamed Abdel-A ziz, 2001). After the Second World War, the main concern of most economists revolves around economic development, and new theories have emerged represented in the theory of the stages of growth for Rostow, the Harrod-Domar model, the theory of structural change, then the theory of strong impulse, the theory of balanced growth strategy (Nirxa), where it depends on The necessity of

This means that the payment schedule for each tranche extends for a period of ten years 4 The principal of the loan is only repaid upon completion of receipt of all payments, and the principal of the loan 5 begins to be paid in 2029 


\section{International Journal of Social Science and Economic Research}

ISSN: $2455-8834$

Volume: 05, Issue: 01 "January 2020"

directing a strong push to a group of integrated consumer industries horizontally to overcome the problem of narrow the scope of the local market by establishing many simultaneous consumer industries and creating many integrated industries, in addition to the need to achieve a balance between industry and agriculture, after that Hirschmann and the theory of unbalanced growth strategy (Abu Al-Saud Mohammad Fawzi, 2004).

Underdevelopment is a phenomenon that reflects the low social, economic, and educational status of a large sector of society and appears in the form of low national income, its growth rate, inequality in its distribution among members of society, and a severe scarcity in the supply of capital in relation to the presentation of other elements of production (Al-Dawi Mohammad Ahmad, 1983), in addition to increasing importance Relativity of the agricultural sector's contribution to national income, high population growth rates, local market constraints, increased dependence on the global market and inadequate infrastructure (Al-Najafi Salem Tawfiq, 2000).

As for sustainable development, it is a process of structural change - by voluntary action - that includes aspects of economic, political, social and cultural life, and works to move society towards the best with the latest quantitative and qualitative changes with the aim of raising the standard of living for all members of society and the continuous improvement of the quality of life, and economic development in its essence is directed to increasing energy Productivity, sustainable development aims to work to eradicate poverty, and sustainable development goals require working in a spirit of partnership in a sustainable manner for future generations. (United Nations Development Program around the world). Economic development programs in Egypt during the period between the fifties and seventies focused on protecting the nascent industry, and in 1973 Egypt adopted a policy of economic openness and increased dependence on foreign financial resources to finance the economic development process, and in 1978 Egypt signed an agreement with the International Monetary Fund that included the adoption of Egypt An economic adjustment program based on credit facilities and financial support provided by the Fund for a period of 3 years amounting to $\$ 720$ million, and then adopted a strategy to encourage exports during the eighties and nineties. (Youssef Mohamed Hassan, 2008). In 1980 the state's public budget deficit worsened, economic growth rates decreased and unemployment rates increased, as prices increased and domestic savings decreased. Egypt implemented a set of economic reform programs recommended by the IMF in 1990 to reduce these effects, but there remained a gap in financial resources that required its coverage to rely on external financing, as it reached 1341 million dollars in the period between 1976 - 1980, then it reached To 12.4 billion dollars in 1980, then 32.6 billion dollars in 1990 (Yusef Muhammad Hassan 2008). The savings gap in the previous three years ranged from $4.1 \%$ in $2010-2011$ to $8.4 \%$ in $2011-2012$ and then to 7\% in 2012-2013 (Ministry of Planning, Egypt, 2019). In February 2016, the Egyptian state adopted the 2030 Egypt sustainable development plan, which aimed to achieve a set of goals that 
included reaching the ratio of public debt / gross domestic product to 50\%, as well as reaching the budget deficit / output $5 \%$ of gross domestic product and that the inflation rate ranges between 3 - 5\% also aspires that the rate of economic growth reach $7 \%$ and that the unemployment rate decrease to $5 \%$ as it aims to have a real per capita gross domestic product of $\$ 7.8$ thousand annually, as well as a net trade balance deficit reaching $4 \%$ of the output (Ministry of Planning, Egypt, Egypt, 2019).

\subsection{Inflation rate}

Inflation rate reached $22.2 \%$ in 1990 , decreased in 1998 to $4.7 \%$, and then decreased in 2000 to $2.8 \%$, but increased to 13.2 in 2009 and then to 12.4 in 2012. Then it reached its peak in 2017, it exceeded $30 \%$. There is no doubt that the high rate of inflation has a negative impact on investment, as it is an expelling factor for investment, as it helps to increase the phenomenon of capital flight abroad. (National Bank of Egypt, 2008).

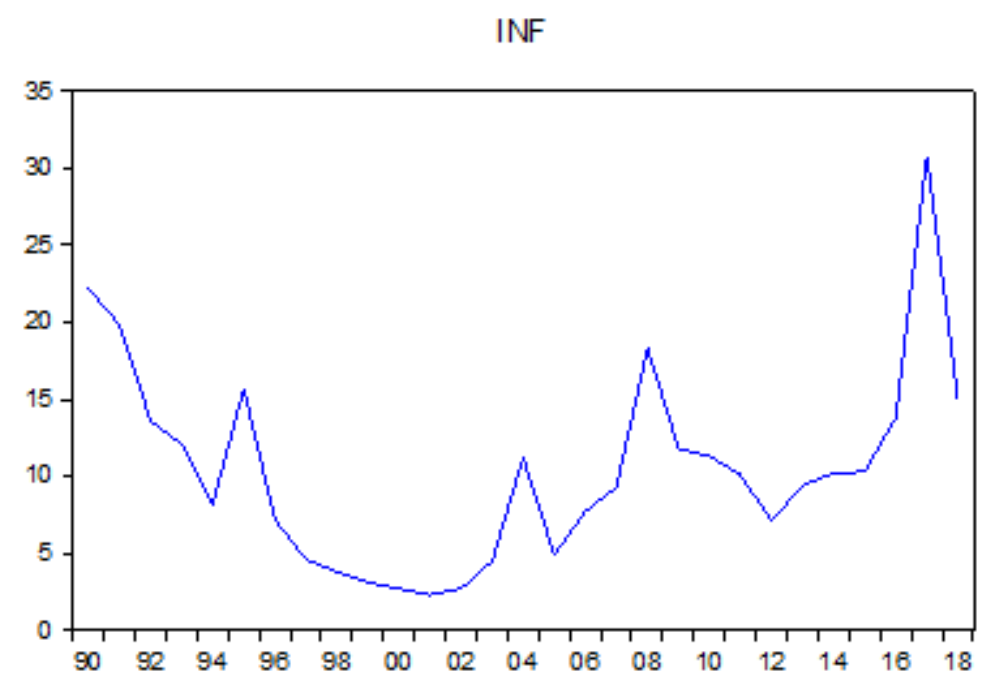

\section{Graphic format designed by the researcher based on World Bank data}

The standard model also showed the correlation between the external debt and the inflation rate INF - when the external debt increases by one unit (billion dollars), the rate of inflation increases by 0.216 units. This reflects the decrease in the degree of flexibility - the degree of the impact of the increase in external debt on the rate of inflation - (knowing that the explanatory power of the model is approximately $26 \%$. 


\section{$I N F=2.385+0.216 E X D$}

\section{INF}

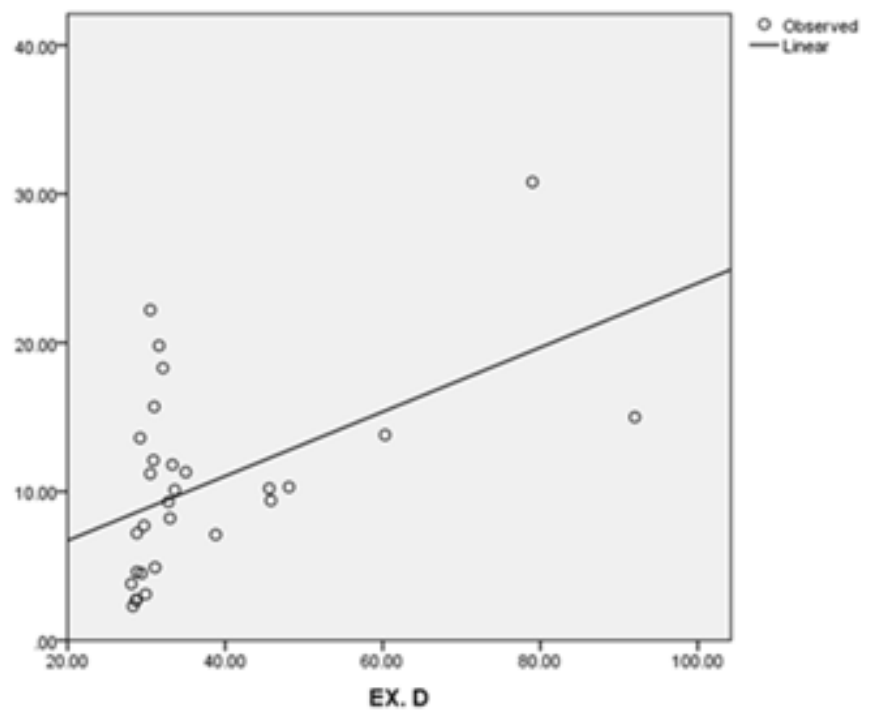

\subsection{The ratio of the public budget deficit to output}

Although the budget deficit to GDP ratio was 3.5\% in 1993 and the lowest value in 1997 was $0.9 \%$, from the year 2000 it rose significantly, reaching its largest value in 2005 where it was 9 . $3 \%$ then reached to $8.3 \%$ in 2009 . The local debt was relied upon to pay off the budget deficit in a noticeable degree where it reaches to 4.3 billion Egyptian pounds was used in 1996 to pay part of the budget deficit while 34.6 billion was used in 2006), which led to a significant increase in the size of the local debt. However, the budget deficit increased to $10.8 \%$ in 2012, then to $13.7 \%$ in 2013, then it decreased to $10.4 \%$ in 2017 and then to 8.2 in 2018. 


\section{$\mathrm{BD}$}

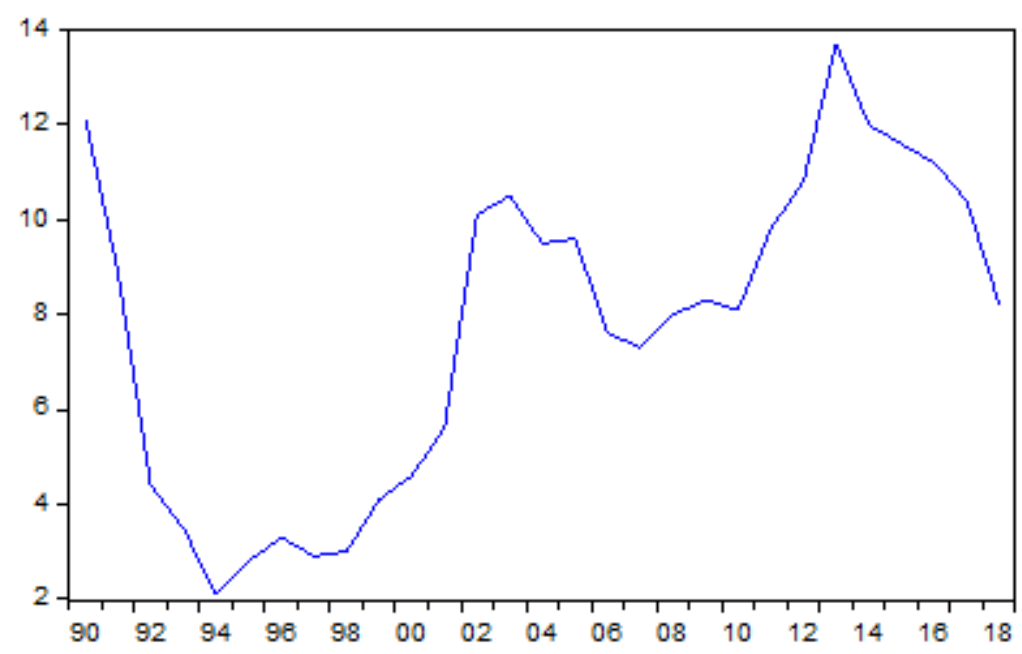

\section{Graphic format designed by the researcher based on World Bank data}

The standard model showed the correlation of the relationship between the external debt EX.D and the public budget deficit BD until the external debt volume reaches $\$ 60$ billion, after which the size of the debt adversely affects the budget deficit.

\section{$B D=-12.001+0.811 E X D-0.007 E X D 2$}

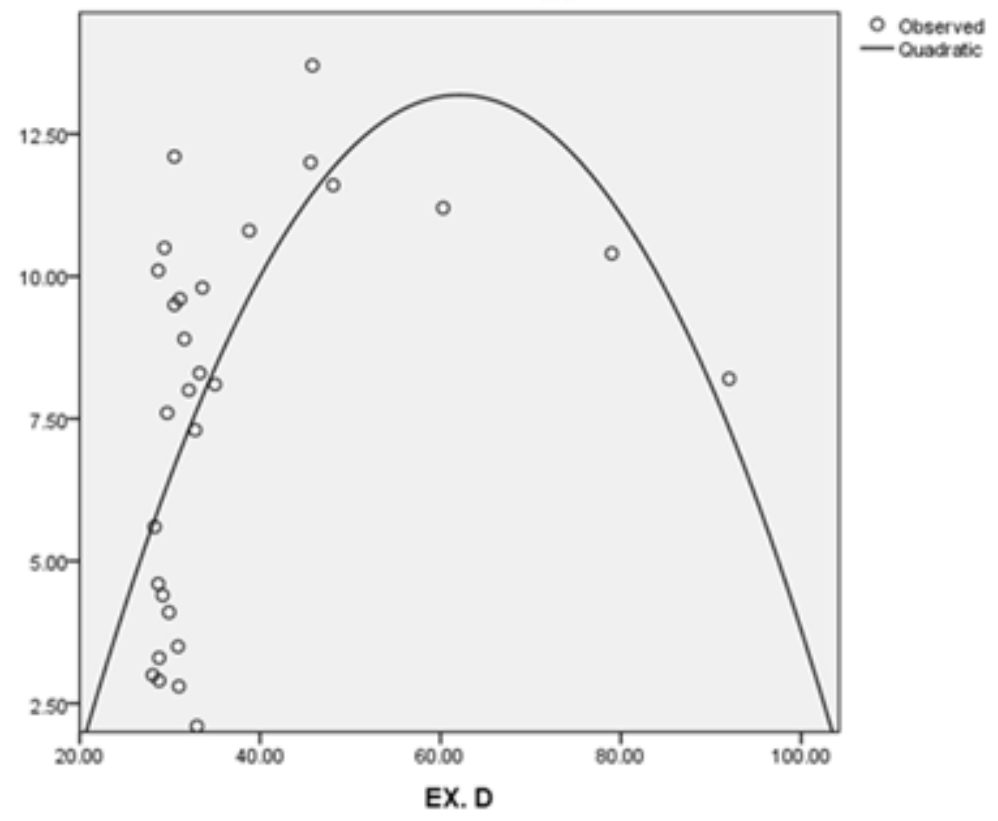




\subsection{Economic growth rates}

The rate of growth declined from an average of $9.4 \%$ in the period from $1975-1980$ to $4.5 \%$ in the period 1990-2001 and then to 3.6 in the period 2001-2004. This decline was associated with a sharp decline in the gross domestic investment rate from $27 \%$ in the period from 1974-1981 to $19 \%$ in the period 1997-2002 and then to $18 \%$ in the period 2003-2006, then the rate of economic growth in 2005 increased from 4.9\% to 6.8\% in 2006 (Egyptian Ministry of Foreign Affairs 2007). However, in 2011 the investment rate declined from 16\% of GDP to about $11 \%$ in the first quarter of 2012-2013, while sustainable development and high economic growth rates require that the investment rate be between 20-25\% of output Gross Domestic (El Faqi Mohammad, 2013). The growth rate fell to its lowest level, reaching 2.1 in 2012-2013. (Egyptian Ministry of Planning). Then it increased in the following years, when it scored 5.1\% in 2018. ( World Bank)

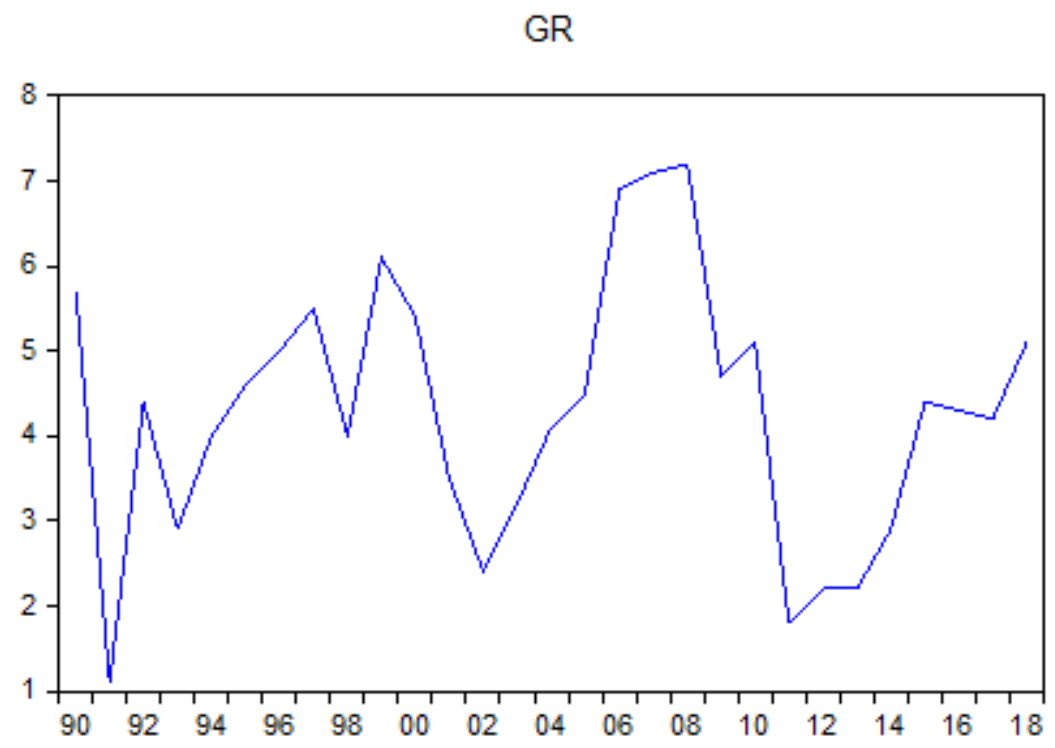

Graphic format designed by the researcher based on World Bank data

All models Linear, Logarithmic, Inverse, Quadratic, and Cubic Compound, Power, Growth, Exponential Logistic $\mathrm{S}$, which clarifies the relationship between GR, EXD is insignificant which means that EXD does not affect GR. 


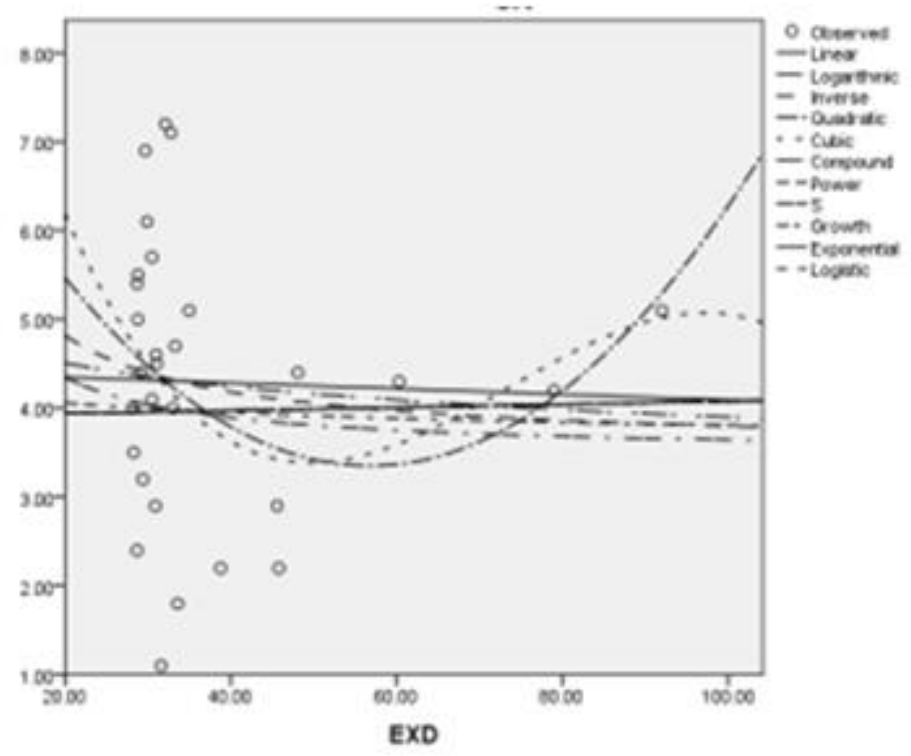

\section{4 unemployment rate}

The unemployment rate in 2000 was about $9 \%$ of the labor force, and in 2005 it reached $11.2 \%$ (Egyptian Cabinet 2006). Despite the efforts made by Egypt since the July Revolution of 1952 to eradicate illiteracy, it is ranked ninth in the world in The illiteracy rate has increased (Arab Planning Institute in Kuwait, 2004) and in the latest estimates of the unemployment rate, in 2013 it reached $13.4 \%$ of the labor force in the Egyptian market. After that, the unemployment rate witnessed a significant decrease in the following years until 2018 witnessed $9.9 \%$ of the total labor force in Egypt.

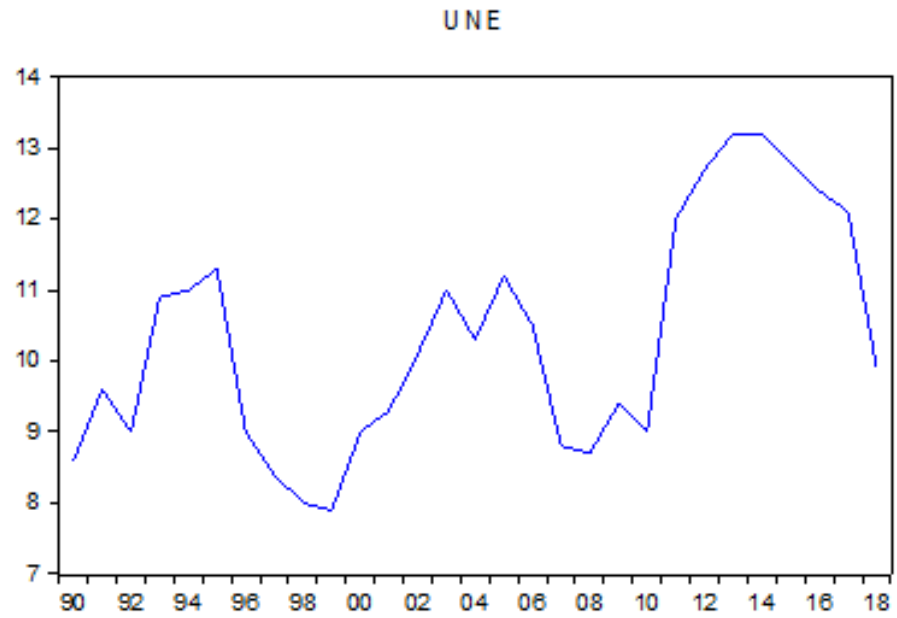

Graphic format designed by the researcher based on World Bank data 
The model showed positive relationship between external debt and the UNE unemployment rate until the external debt volume reached $\$ 60$ billion, and then the debt size adversely affects the unemployment rate.

\section{$U N E=-1.575+0.493 E X D-0.004 E X D 2$}

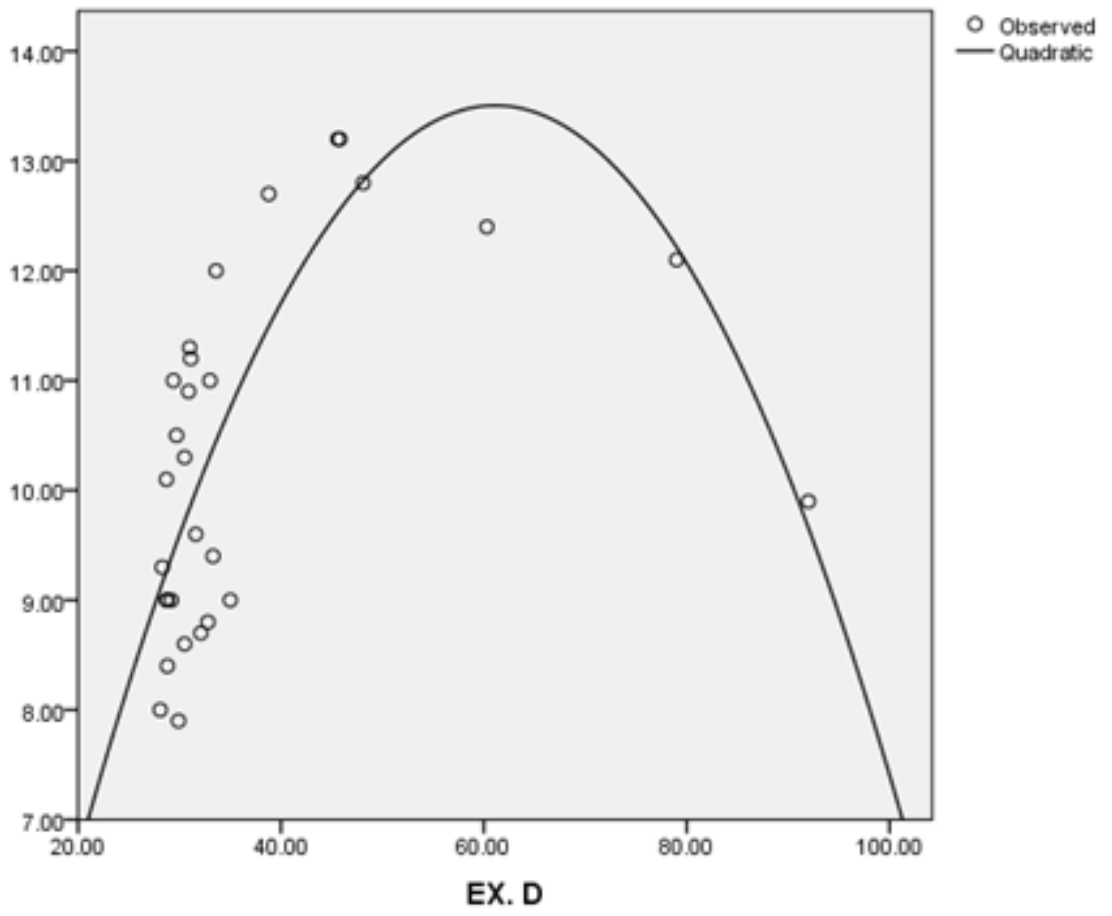

\subsection{Per capita gross domestic product}

The average per capita product in 1990 was about 3800 pounds annually, and it settled almost around these borders until 1995, when it rose to 4143 pounds, then scored 5018 in 2000, then 7693 in 2005, then jumped to 13659 in 2009, then decreased to almost 10019 in 2010, and in 2018 it reached to approximately 11013 Egyptian pounds. 
International Journal of Social Science and Economic Research

ISSN: $2455-8834$

Volume: 05, Issue: 01 "January 2020"

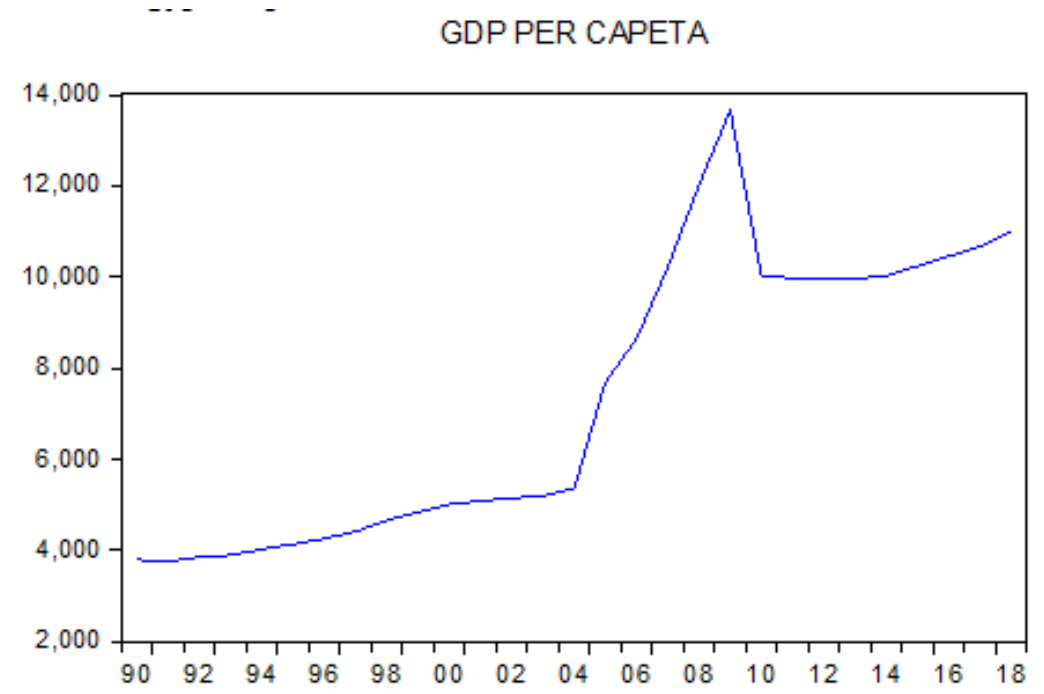

\section{Graphic format designed by the researcher based on World Bank data}

The model also showed the correlation between the external debt and the GDP per capita, as the coefficient is negative for the reciprocal of the independent variable (external debt), which means that when the external debt increases by one unit (billion dollars), the per capita gross domestic product will increase by 296388.273 pounds, which means that an increase in external debt by one dollar increases the per capita gross domestic product by 0.029638827 pounds, (296388.273 $/ 10,000000)$.

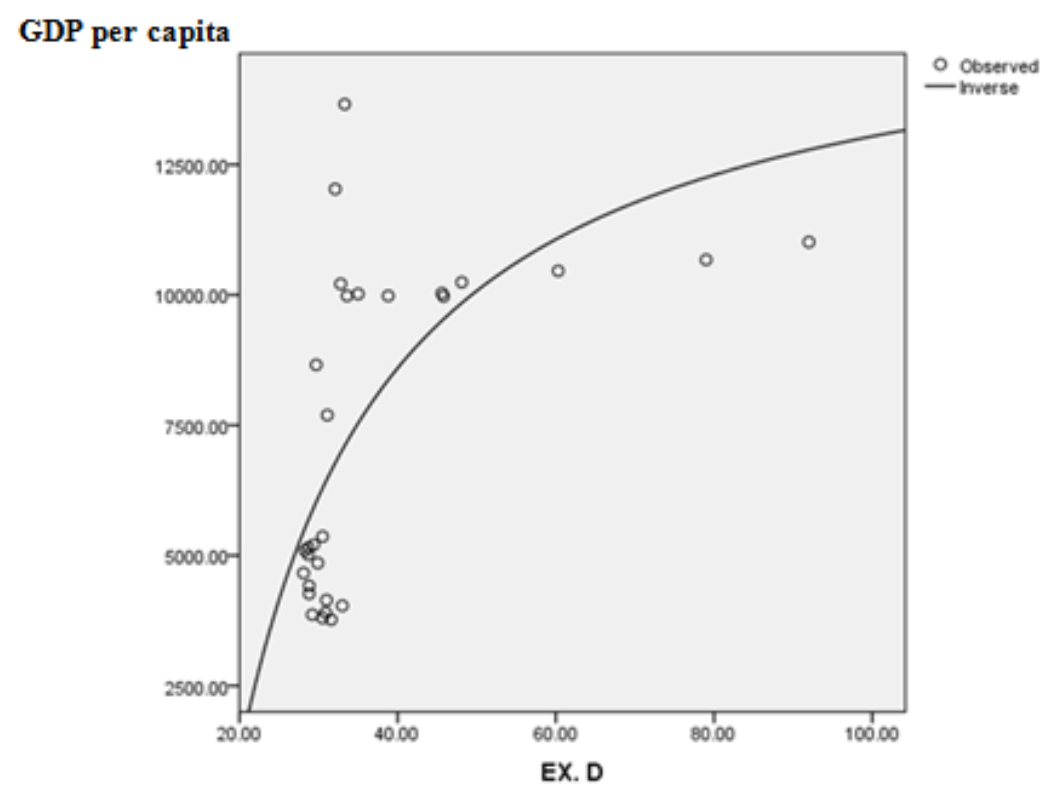




\subsection{Trade deficit}

The Egyptian Trade Balance achieved a continuous deficit for consecutive and long periods. It recorded a deficit of about $8 \%$ of the gross domestic product in 1990, and then it decreased to 5.4\% in 1995 and then $4.9 \%$ in 2000. Although the Egyptian trade balance continued to achieve a continuous deficit, that deficit decreased to $1.6 \%$ in 2005 , then this deficit increased again in 2010 to $4.1 \%$, and then jumped to $9.3 \%$ in 2015 before stabilizing in 2018 at $13.4 \%$.

TBD

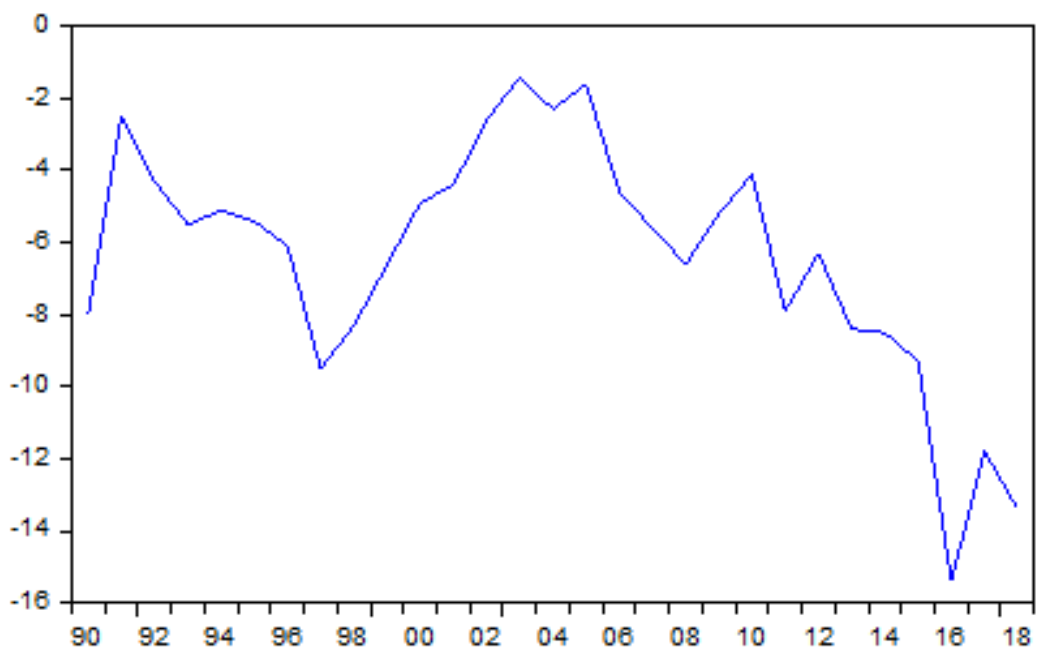

Graphic format designed by the researcher based on World Bank data

The standard model demonstrated the inverse relationship between external debt EXD and TBD trade balance deficit. This means that when the external debt increases by one unit (one billion dollars), the trade balance deficit decreases by 0.162 , (a decrease of $16 \%$ of the trade balance deficit). 


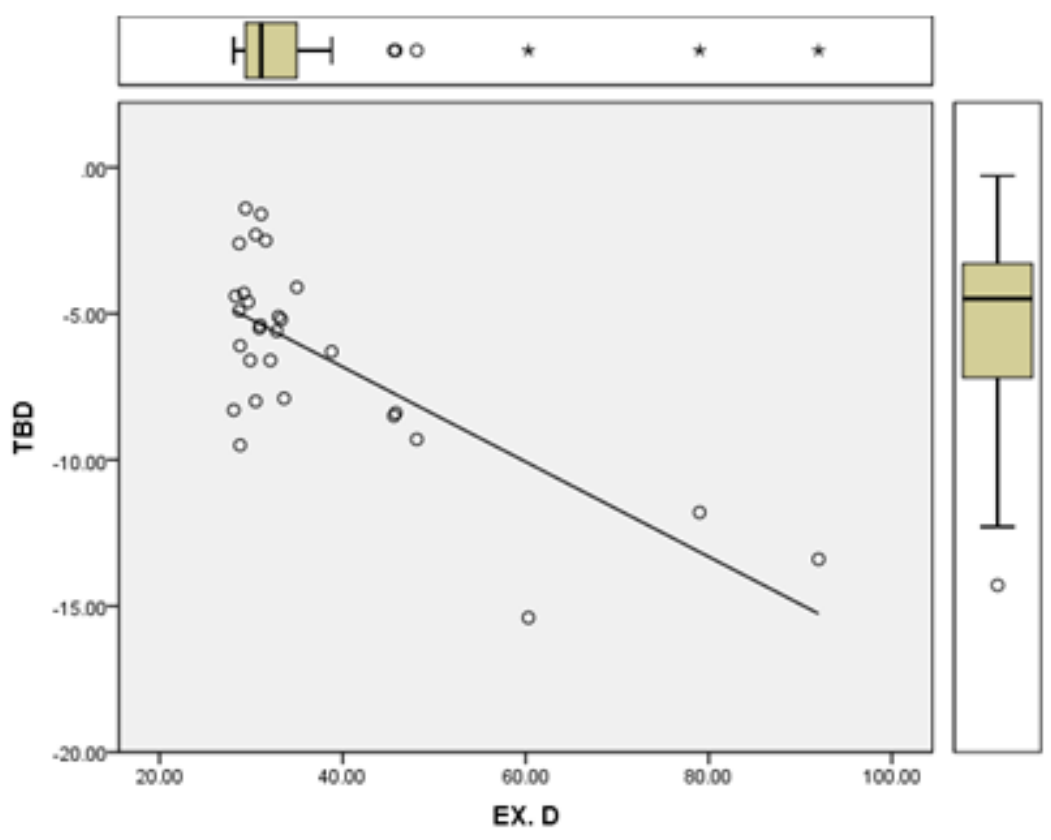

\section{THE CONDITION OF SUSTAINING THE EXTERNAL DEBT TO ENSURE A POSITIVE IMPACT ON THE SUSTAINABLE DEVELOPMENT GOALS}

It can be said that the results of the standard model predicts that the impact of the development of the Egyptian external debt, despite its noticeable increase, does not affect negatively except on the rate of inflation and within narrow limits as previously explained, and that its effect is positive on the per capita product, provided that the external debt is directed to investment. According to the World Bank, the Egyptian external debt falls mostly in the long-term debt category $^{6}$, so in 2010 it reached about $88 \%$, and by the end of December 2019 the proportion was about $89.8 \%$ in $2019^{7}$, and its value is $\$ 97.6$ billion in 2019 , and the rest is worth $\$ 11.055$ billion in external debt Short term. ${ }^{8}$

\begin{tabular}{|c|c|c|c|c|c|c|c|c|c|c|}
\hline Year & $\mathbf{2 0 1 0}$ & $\mathbf{2 0 1 1}$ & $\mathbf{2 0 1 2}$ & $\mathbf{2 0 1 3}$ & $\mathbf{2 0 1 4}$ & $\mathbf{2 0 1 5}$ & $\mathbf{2 0 1 6}$ & $\mathbf{2 0 1 7}$ & $\mathbf{2 0 1 8}$ & $\mathbf{2 0 1 9}$ \\
\hline Ratio & $\mathbf{8 8 \%}$ & $\mathbf{8 6 \%}$ & $\mathbf{8 0 \%}$ & $\mathbf{9 1 \%}$ & $\mathbf{9 0 \%}$ & $\mathbf{8 8 \%}$ & $\mathbf{7 7 \%}$ & $\mathbf{7 9 \%}$ & $\mathbf{8 0 \%}$ & $\mathbf{8 9 . 8 \%}$ \\
\hline
\end{tabular}

Long-term external debt ratio / total external debt the ratio is calculated by the researcher based on World Bank data

But there remains an important point that must be taken into consideration, namely ensuring the payment of installments and interest on external debt regularly at the time of maturity, especially

The original maturity of more than 12 months ${ }^{6}$ It was calculated by the researcher based on the data of the World Bank ${ }^{7}$

The maturity period is less than 12 months $^{8}$ 


\section{International Journal of Social Science and Economic Research}

ISSN: $2455-8834$

Volume: 05, Issue: 01 "January 2020"

with the start of repaying the IMF loan of $\$ 12$ billion. The sustainability of debt or financial solvency is the ability of the state to meet its debt obligations on an ongoing basis (Arab Planning Institute, Kuwait, 2004). One of the indicators of debt sustainability is the debt / exports index, and it measures the percentage of exports that convert to debt service, as well as shows the fragility of debt service for an unexpected decrease in exports (Arab Planning Institute, Kuwait, 2004). Comparing external debt service to exports, we find that it increased from $5.7 \%$ in the year 2011 to $19.7 \%$ in 2017 . The rise in this indicator indicates that debt has become greater than the main source of the country's hard currency (Egyptian Ministry of Finance, 2019). Also, the debt index to the gross domestic product, as this indicator reflects the ratio of total resources available for debt servicing through the transfer of resources from the production of local goods to the production of exports. The ratio of the local debt to the gross domestic product in 1994 was about 55\%, while in 2005 it reached 65\% at a growth rate, it exceeds much the rate of growth of the gross domestic product in Egypt (Salman Ibrahim Nassar, 2000), which in the same year was only about 7.4\% (Affan (Manal 2009). However, this ratio exceeded $100 \%$ of output through 2016-2018 (World Bank, 2019). The total external debt service as a percentage of the gross domestic product is constantly increasing, recording $28.7 \%$ in 2001, 33.9 in 2002, 37.7 in 2003, then 39.6 in 2004 (Arab Monetary Fund Report, 2007). By comparing the external debt service to the current receipts, it found that it is constantly increasing, as it was 4.5 in 2011 and reached 12.3 in 2017, and the total external public debt to GDP in 2011 increased from $15.2 \%$ to $41.2 \%$ in 2017, as well as increasing the share Per capita external debt from \$ 413.6 per capita in 2011 to \$ 883.9 in 2017 (Egyptian Ministry of Finance, 2019)

\section{FINDINGS AND RECOMMENDATIONS}

It conclude from the above analysis that the Egyptian external debt, despite its significant increase in the past few years from 2016 to 2019, but its impact on the targeted economic variables in the sustainable development plan "Egypt 2030" is positive in predominance provided that it is employed in investment fields, as this result depends on the sustainability of the Egyptian public debt, especially the external debt, the ability to pay the installments and interest on their due dates, especially after obtaining the full IMF loan in full and the Russian loan to finance the nuclear energy project in Dabaa, which requires a review of the public debt management policy. We also conclude that the hypothesis of the influence of external debt has a different effect on the variables of the sustainable development plan "Egypt 2030" is correct, after testing it in the standard model, where its impact is positive on some variables , and negative on the others. 


\section{International Journal of Social Science and Economic Research}

ISSN: $2455-8834$

Volume: 05, Issue: 01 "January 2020"

Therefore, the research recommends the necessity of reviewing the public debt management policy in Egypt to ensure the sustainability of the Egyptian public debt, especially the external debt. It also requires working to attract more foreign direct investment at the expense of expanding the external debt to bridge the financing gap that the Egyptian economy suffers from. It should also be noted that increasing the external debt with following the floating exchange rate policy means increasing the public debt by double amounts due to the high price of the dollar against the Egyptian pound, and here the importance of following the policy of expansion in attracting foreign investment at the expense of expanding in external debt appears. Also, reaching the ratio of public debt / gross domestic product to $50 \%$ requires an increase in productivity, which requires the optimal use of available resources and a reduction in the unemployment rate on the one hand and not increasing the public debt on the other hand, which requires dependence on foreign direct investment instead of increasing the external debt, and it has become clear Increasing the rate of inflation whenever the external debt increases, which does not achieve the goal of achieving inflation rates to the target of $3-5 \%$, so it must limit the increase in dependence on external debt.

\section{REFERENCES}

1. Abu Al-Saud, Mohammad Fawzi, 2004, Introduction to Macroeconomics, University House, Alexandria

2. Al-Basha \&others.,2014, Measuring the Impact of External Finance on Economic Growth in Jordan, An Analytical Standard Study for the Period (1997-2011), College of Economics and Administrative Sciences, Zarqa University, Jordan .pp. 3-6

3. Al Najafi, Salem Tawfiq,2000, fundamental of Economics, International House for Cultural Investments, Egypt, , pp15-22

4. Affan, Manal, 2009, Evaluation of the Use of Economic Policy Tools in Achieving Economic Balance, a study on the Egyptian economy with reference to the experiences of newly industrialized countries, PhD thesis, University of Tanta

5. Arab Monetary Fund, 2007, Consolidated Arab Economic Report, 2007, Balance of Payments, External Public Debt, and Exchange Rates

6. Arab Monetary Fund, 2007, balance of payments, external public debt, and exchange rates. Consolidated Arab Economic Report

7. Arab Planning Institute in Kuwait,2004, the official website on the Internet, home page , http://www.arab-api.org/

8. Al-Dawi, Mohammad Ahmad 1983, Economic Underdevelopment, University Press Office, Algeria

9. Ajamia, Mohamed Abdel Aziz , 2001, Economic Development, University House, Alexandria, pp. 6-9 


\section{International Journal of Social Science and Economic Research}

Volume: 05, Issue: 01 "January 2020"

10. Benjamin Fredman, 1988, Day of Reckoning, N. Y. New York, Random House, p 2

11. Diamond, Peter, 1965,'Economic Growth’, American Economic Review, 55, pp. 11251150

12. Ejigayehu, Dereje Abere,2013, The effect of external debt on Economic Growth: A panel data analysis on the relationship between external debt and economic growth, Södertörns högskola, p1

13. Egyptian Cabinet, 2006, Information and Decision Support Center, business owners opinion poll on labor market needs

14. Egyptian Ministry of Finance,2013, http://www.mof.gov.eg/Arabic/Pages/Home.aspx

15. Egyptian Ministry of Finance,2019, http://www.mof.gov.eg/Arabic/Pages/Home.aspx

16. EIPR, Personality, 2017, Egyptian Initiative for Personal Rights, Concerns: External debt in Egypt, 14 Grand Serial Street ,Fouad Serag El Din, 'Garden City, Cairo

17. El Feky, Mohamed, 2013, Great Challenges for the Central Bank to Lift the Economy from its Stumbling, Al-Ahram Economic, February 2013, http://digital.ahram.org.eg/articles.aspx

18. Jayaraman, T.K ,2008, "Does external debt lead to economic growth in pacific Island countries" journal of policy modeling

19. Pentor, Al-Mustafa., 2018, Arab Monetary Fund, the Limits of Sustainable Public Debt and Economic Growth between Theory and Reality: Projections on the Case of Arab Countries, September. P1

20. Ministry of Planning, Follow-up and Administrative Reform, Sustainable Development Strategy - Egypt 2030, Egypt Vision 2030, Arab Republic of Egypt, Ministry of Planning official website, http://mpmar.gov.eg/, 2019

21. Ministry of Foreign Affairs, Arab Republic of Egypt, Evolution of the Performance of the Egyptian Economy, Egyptian Economy Bulletin 9/1/2007, p. 1

22. Moussa, Ibrahim ,2009, Measuring and Analyzing the Impact of International Financial Flows on Economic Development in Selected Developing Countries During the Period 1990, Journal of Baghdad College of Economic sciences University, ISSN: 2072778X Issue: 19 Pages: 5-8

23. Mustafa Samir, 2015, The Impact of External Debt on Economic Growth, The Case of Some Borrowing Arab Countries, Faculty of Economics and Administrative Sciences, AlAzhar University, Gaza Strip, Palestine, pp.6-7

24. National Bank of Egypt, 2008, The Performance of the Egyptian Economy in 2007, Economic Bulletin, Sixty-first Volume

25. Omar, Mohamed Abdel-Halim ,2003, Public Religion Concepts - Indicators - Effects, applying the case of Egypt, Al-Azhar University, December , p. 2 
26. Salman, Ibrahim Nassar, 2000, Financial Policy and its Role in Economic Development in Developing Countries (with special reference to Egypt) Survey Study, Faculty of Commerce, Ain Shams University

27. Shalaby, Nadia, 2014, The Extent of Egypt Benefiting from its Relationship with the International Monetary Fund During the Period (1945-2011) "A Comparative Study", Department of Economics, Faculty of Commerce, Ain Shams University, p. 2

28. The Egyptian Ministry of Finance, 2007, Evolution of the State's Budget Deficit (Reasons Effects - Solutions), Minister's Office Sector, Central Department for Financial Research and Administrative Development, p. 11

29. The Arab Planning Institute, 2004, External Debt Management, a periodic series concerned with development issues in the Arab countries, number thirty and June, third year, p. 7, Kuwait

30. World Bank, 2019, The official website on the internet. Data, Egypt, https://data.albankaldawli.org/country/eg

31. United Nations Development Program around the world, https://www.eg.undp.org/content/egypt/ar/home/ourwork/sustainabledevelopment/overview.html

32. Yalgin Suleiman, 2013, Prospects for Economic Growth in Developing Countries in the Light of External Debt, An Analytical Study of a Sample from Southeast Asian Countries, College of Administration and Economics, Kirkuk Journal of Administrative and Economic Sciences, Volume 3, Issue 1, pp. 4-7

33. Youssef, Mohamed Hassan, 2008, Evaluation of Development Experiences in the Middle East, https://www.saaid.net/Doat/hasn/128.htm 